\title{
Bipolar distribution of the cyst-forming dinoflagellate Polarella glacialis
}

Received: 9 August 2002/ Accepted: 7 December 2002/Published online: 23 January 2003

(C) Springer-Verlag 2003

\begin{abstract}
Morphological investigations of motile cells and cysts of a small dinoflagellate (strain CCMP 2088) isolated from Canadian Arctic waters were carried out under both light and scanning electron microscopy. This species strongly resembled Polarella glacialis (strain CCMP 1383), which up to now was known only from Antarctic sea ice. The photosynthetic pigment composition of strain CCMP 2088 is typical of dinoflagellates, with peridinin as a major accessory pigment. Phylogenetic relationships between the two strains and other dinoflagellate species were inferred from SSU nrDNA using Neighbour Joining and weighted parsimony analyses. Our results showed that strain CCMP 2088 and $P$. glacialis (strain CCMP 1383) grouped in the same clade (Suessiales clade), showing high similarity values $(0.99 \%)$. Morphological and molecular data support the assignment of the Arctic strain to P. glacialis. The free-living Gymnodinium simplex and the two P. glacialis strains have a basal position in the Suessiales clade, as compared to Symbiodinium spp.
\end{abstract}

M. Montresor $(\varangle) \cdot$ L. Orsini $\cdot$ G. Procaccini

Stazione Zoologica "A. Dohrn",

Villa Comunale, 80121 Naples, Italy

E-mail: mmontr@szn.it

Fax: + 39-081-7641355

C. Lovejoy

GIROQ, Biologie, Pavillon Vachon,

Université Laval, G1K 7P4, Quebec, Canada

S. Roy

Institut des Sciences de la Mer de Rimouski and Québec-Océan, Université du Québec à Rimouski, 310 Allée des Ursulines, G5L 3A1 Rimouski, Quebec, Canada

Present address: C. Lovejoy

Institut de Ciències del Mar, CMIMA,

Passeig Maritim de la Barceloneta 37-49,

08003 Barcelona, Spain

\section{Introduction}

Polarella glacialis is a small photosynthetic dinoflagellate originally described from the Ross Sea (Antarctica) (Montresor et al. 1999). Under light microscopy, P. glacialis appears as a small, featureless, unarmoured dinoflagellate. However, ultrastructural studies reveal the presence of thin thecal plates with a distinct plate pattern which supports its placement in the order Suessiales (Montresor et al. 1999). This order groups species with a peculiar plate pattern, composed of seven to ten latitudinal series of plates (Fensome et al. 1993). Both endosymbiotic dinoflagellates belonging to the genus Symbiodinium (also known as "Zooxanthellae") and freeliving species, as $P$. glacialis, are included in the order Suessiales. Molecular phylogenetic data based on sequences of the small subunit of the nuclear rDNA (SSU rDNA) support the monophyletic origin of the order Suessiales within the dinoflagellate lineage (Saunders et al. 1997; Montresor et al. 1999; Saldarriaga et al. 2001).

$P$. glacialis blooms in sea-ice brine channels, where it contributes a substantial fraction of the phytoflagellate biomass and primary production (Stoecker et al. 1998, 2000). It forms spiny cysts and high concentrations of these resting stages are often recorded in the sea ice and underlying water column (Garrison and Buck 1989; Buck et al. 1992; Stoecker et al. 1992). This extremely halotolerant species blooms in the sea ice during the spring, when grazing pressure is relatively low, and subsequently encysts at the beginning of the austral summer (Stoecker et al. 1997, 1998).

Spiny cysts closely resembling those produced by $P$. glacialis have been reported also from the Arctic. To our knowledge, the first report dates back to the beginning of the last century, when Meunier (1910) described several species of the genus Echinus from the Kara and Barents Seas. Two of these species, Echinus majus and E. minus, morphologically resemble the resting cyst of $P$. glacialis (Table IV in Meunier 1910). Similar resting stages have also been reported from the 
Greenland (Ikävalko and Gradinger 1997) and Russian Arctic Seas (Okolodkov 1998).

Motile gymnodinioid cells were isolated from seawater samples collected at the ice edge in the northern region of the North Water Polynya [between Ellesmere Island (Canada) and Greenland] in early April 1998. The formation of spiny resting cysts resembling those produced by $P$. glacialis was observed in cultured material and prompted us to investigate the relationship between this Arctic "gymnodinioid" isolate and P. glacialis. We studied the morphology of motile cells and cysts under light and scanning electron microscopy (SEM) and sequenced the SSU of the nuclear rDNA in order to infer phylogenetic relationships among the Arctic isolate and a large number of dinoflagellate species.

\section{Materials and methods}

\section{Cultures and SEM preparation}

As part of the North Water Polynya Project aboard the Canadian Coast Guard Icebreaker Pierre Radisson, phytoplankton samples were collected with a Niskin bottle mounted on a CTD Rosette system in northern Baffin Bay on 10 April 1998. A seawater sample was collected at a depth of $6 \mathrm{~m}$, adjacent to a $63-\mathrm{cm}$-thick ice edge $\left(78^{\circ} 35^{\prime} 32^{\circ} \mathrm{W}\right.$ and $\left.74^{\circ} 29^{\prime} 32^{\circ} \mathrm{N}\right)$. Phytoplankton biomass was dominated by the ribbon-forming pennate diatom Navicula septentrionalis (Grunow) Gran $\left(3 \cdot 10^{4}\right.$ cells $\left.1^{-1}\right)$ and by small $(2-10 \mu \mathrm{m})$ flagellates $\left(1 \cdot 10^{5}\right.$ cells $\left.1^{-1}\right)$. Concentrations of gymnodinioid cells, resembling $P$. glacialis, were ca. $2 \cdot 10^{3}$ cells $1^{-1}$ and no spiny cysts were seen in the sample or in an ice core collected in the adjacent ice (M. Gosselin, personal communication). The water sample was filtered through a sterile $2-\mu \mathrm{m}$ polycarbonate filter, which was placed in $0.2 \mu \mathrm{m}$ filtered local seawater $(35 \mathrm{psu})$ at $0{ }^{\circ} \mathrm{C}$, and incubated under low light (ca. $20 \mu \mathrm{mol}$ photons $\mathrm{m}^{-2} \mathrm{~s}^{-1}$ ) for 4 weeks. A unialgal culture was subsequently obtained in the laboratory using the serial dilution method (Throndsen 1995). The culture was deposited at the Provasoli-Guillard National Center for Culture of Marine Phytoplankton (CCMP 2088). At the Stazione Zoologica, the culture was maintained in K medium (Keller et al. 1987) prepared with Mediterranean oligotrophic seawater adjusted to a salinity of $32 \mathrm{psu}$ by the addition of sterile bi-distilled water. The culture was grown at a temperature of $2^{\circ} \mathrm{C}$ in continuous light (ca. $30 \mu \mathrm{mol}$ photons $\mathrm{m}^{-2} \mathrm{~s}^{-1}$ ) provided by cool-white fluorescent tubes.

Thirty cells and 20 cysts were measured under the light microscope at $\times 1,000$. Motile cells and cysts were prepared for SEM examinations by fixation with $2 \%$ (final concentration) osmium tetroxide for $10 \mathrm{~min}$. Cells were then rinsed twice with filtered seawater, placed on a Nuclepore filter, dehydrated with an ethanol series, critical-point dried and coated with gold. The material was examined with a Philips 505 scanning electron microscope.

\section{Pigment analysis}

Duplicate culture samples $(3 \mathrm{ml})$ were filtered on $\mathrm{GF} / \mathrm{F} 25-\mathrm{mm}$ filters, which were extracted in $3 \mathrm{ml} \mathrm{95 \%} \mathrm{methanol} \mathrm{(v:v)} \mathrm{and} \mathrm{so-}$ nicated on ice. The extracts were cleared using a $0.22-\mu \mathrm{m}$ Acrodisc filter (Gelman). A 50-ml volume of the extracts was injected in a Thermo Separation P4000 pump and separation was done on a reversed phase C8 Symmetry column (Waters, $150 \times 4.6 \mathrm{~mm}$, $3.5 \mu \mathrm{m})$ thermostated at $25^{\circ} \mathrm{C}$ using a refrigerated circulator water bath connected to an HPLC-column water jacket (Alltech). The peaks were detected simultaneously by a fluorescence detector (Spectroflow 980) and a fast-scanning absorbance detector (Spectra Focus, scans from 400 to $700 \mathrm{~nm}$ ). The method of Zapata et al. (2000) was followed for elution using their mobile phase A (methanol:acetonitrile:aqueous pyridine; 50:25:25 v:v:v) and B1 (methanol:acetonitrile:acetone; 20:60:20 v:v:v), with A varying from $100 \%$ to $60 \%$ in $22 \mathrm{~min}$, then decreasing to $5 \%$ at $28 \mathrm{~min}$, maintained stable from 28 to $38 \mathrm{~min}$ and brought back to $100 \%$ at $40 \mathrm{~min}$ at a flow rate of $1 \mathrm{ml} \mathrm{min}{ }^{-1}$. Peaks were identified based on retention time and spectral match with external pigment standards. Pigments were quantified using calibration curves constructed with commercially available standards (chlorophyll $c_{2}, \beta, \beta$-carotene, peridinin, diadinoxanthin and diatoxanthin from DHI Water \& Environment, Denmark; chlorophyll $a$ from Fluka).

\section{Phylogenetic analysis}

DNA was extracted from $200 \mathrm{ml}$ of exponentially growing cultures, following Klimyuk et al. (1993). The rDNA SSU was amplified using the universal primers ss5 and ss3 (Rowan and Powers 1992) in a PCR express thermal cycler (Hybaid). Genomic DNA (20 ng) was amplified in $20 \mu \mathrm{l}$ reaction mix containing $0.5 U$ of Taq Polymerase (Boeringer, Mannheim), $0.04 \mathrm{mmol}$ of each nucleotide and $20 \mathrm{pmol}$ of each primer. Forty cycles $\left(1 \mathrm{~min}\right.$ at $94^{\circ} \mathrm{C}, 1.5 \mathrm{~min}$ at $55^{\circ} \mathrm{C}, 1 \mathrm{~min}$ at $72^{\circ} \mathrm{C}$ ), with an initial denaturation step of $5 \mathrm{~min}$ at $95^{\circ} \mathrm{C}$, were performed. Amplified DNA fragments were purified with the QUIAEX II purification kit (Qiagen). Purified PCR fragments were cloned in TA vector with the TA cloning kit, according to the manufacturer's instructions (Invotrigen). Vector primers (M13rv and T7) and four internal primers (Table 1) were used as sequencing primers. Sequences were obtained with a Beckman Ceq 2000 Automatic sequencer, using a Dye-Terminator cycle sequencing kit (Beckman).

We increased the number of sequences included in the phylogenetic analysis presented by Montresor et al. (1999), adding sequences of several Symbiodinium species in order to better test relationships among species of the order Suessiales. The $18 \mathrm{~S}$ sequence obtained from the Arctic strain CCMP 2088 was aligned with other dinoflagellate sequences available in GenBank (Saunders et al. 1997; Montresor et al. 1999 and Table 2) using Clustal W (Thompson et al. 1994) in the Bioedit 4.5 .8 computer package (Hall 1999). Perkinsus marinus, Perkinsus sp. (Perkinsida) and Sarcocystis muris (Sporozoa) were used as outgroups in the phylogenetic analysis, which was inferred using both distance and parsimony analyses. To assess the phylogenetic informativeness of our data set, $g 1$ and the skewness of the distribution of tree-lengths among the parsimony trees (Sokal and Rohlf 1981; Hillis and Huelsenbeck 1992) were evaluated using PAUP* (Swofford 2002). Significance of $g 1$ was compared with critical values $(P=0.01)$ for 4 -state characters given 554 parsimony informative sites and 50 distinct taxa (Hillis and Huelsenbeck 1992). Neighbour Joining (NJ) trees were obtained according to the Kimura-3-parameter model, using Neighbour option. Weighted parsimony (MP) trees were inferred using PAUP* (Swofford 2002). The MP tree is based on 27 MP trees and it was generated using the heuristic search TBR (tree bisection reconnection) branch swapping option and Goloboff fit criterion $(K=2)$. In both analyses, bootstrap support was calcu-
Table 1 Specific internal primers used in sequencingre actions $(F=$ forward, $R=$ reverse)

\begin{tabular}{llll}
\hline Primer code & Direction & Sequence (5'-3') & Position in the sequence \\
\hline PgA-F2 & $\mathrm{F}$ & CTAGAGCTAATACATGCACCAAAA & $149-173$ \\
PgA-F3 & $\mathrm{F}$ & TCCAGCTCCAATAGCGTATATTAA & $572-596$ \\
PgA-F5 & $\mathrm{R}$ & AGAGTTTGATTCTCATAAGGTGC & $1089-1065$ \\
PgA-R1 & $\mathrm{R}$ & CAATGATCTATCCCCATCACGATG & $1548-1524$
\end{tabular}


Table 2 Strains included in the phylogenetic analysis and GenBank accession numbers of their SSU rDNA sequences. For taxa not listed in this table, see Saunders et al. (1997) and Montresor et al. (1999)

\author{
${ }^{a}$ The numbers listed in \\ brackets identify the different \\ symbiodinium strains on the \\ phylogenetic tree in Fig. 3
}

\begin{tabular}{|c|c|c|}
\hline Species & Literature reference & $\begin{array}{l}\text { GenBank } \\
\text { accession number }\end{array}$ \\
\hline Amyloodinium ocellatum & Litaker etal. (1999) & AF080096 \\
\hline Gymnodinium beii & Gast and Caron (1996) & U41087 \\
\hline G. breve & Tengs et al. (2000) & AF172714 \\
\hline G. galatheanum & Tengs et al. (2000) & AF172712 \\
\hline G. simplex & Gast and Caron (1996) & U41086 \\
\hline G. varians, strain CCMP 421 & Saldarriaga et al. (2001) & AF274279 \\
\hline Gyrodinium aureolum, strain KT-77D & Tengs et al. (2000) & AF172713 \\
\hline Pfiesteria piscicida & Oldach et al. (2000) & AF077055 \\
\hline Pfiesteria sp. & Oldach et al. (2000) & AF218805 \\
\hline Polarella glacialis, strain CCMP 2088 & This study & AY179607 \\
\hline Symbiodinium sp., type A $(\text { Symbiodinium sp. } 1)^{\mathrm{a}}$ & Tolleret al. (2001) & AF238256 \\
\hline Symbiodinium sp., type E (Symbiodinium sp. 2) ${ }^{\mathrm{a}}$ & Tolleret al. (2001) & AF238261 \\
\hline Symbiodinium sp. $(\text { Symbiodinium sp. } 3)^{\mathrm{a}}$ & Langer and Lipps (1995) & AF 182822 \\
\hline Symbiodinium sp., strain Fs1 (Symbiodinium sp. 4) ${ }^{\mathrm{a}}$ & Darius et al.(2000) & AJ 271765 \\
\hline Symbiodinium sp., strain Gf4 (Symbiodinium sp. 5) ${ }^{\mathrm{a}}$ & Darius et al.(2000) & $\mathrm{AJ} 271755$ \\
\hline Symbiodinium sp., strain PLCC-1 (Symbiodinium sp. 6) ${ }^{\mathrm{a}}$ & Carloset al. (1999) & AB016538 \\
\hline Symbiodinium sp., strain CS-156 (Symbiodinium sp. 7$)^{\mathrm{a}}$ & Carloset al. (1999) & AB016594 \\
\hline
\end{tabular}

lated using 1,000 bootstrap replicates. Genetic distance and sequence polymorphism between Polarella glacialis (strain CCMP 1383) and the Arctic strain CCMP 2088 were evaluated using Bioedit 4.5.8 (Hall 1999) and DNAsp 3.0 version (Rozas and Rozas 1999), respectively.

\section{Results}

\section{Morphology}

The morphology of motile cells and cysts of strain CCMP 2088 fit within those described for Polarella glacialis, strain CCMP 1383 (Montresor et al. 1999). Strain CCMP 2088 motile cells are $9.0-14.3 \mu \mathrm{m}$ long and $6-10.8 \mu \mathrm{m}$ wide. The epitheca is rounded and the hypotheca is slightly elongated and dorso-ventrally flattened (Fig. 1A-F). Three longitudinal series of thin thecal plates are visible on the epitheca, two in the cingulum (Fig. 1D, E) and four in the hypotheca. No apical groove or acrobase is present on the epitheca (Fig. 1B). The thecal plate arrangement in the sulcal area is only partially visible (Fig. 1A). Cysts are 11.6-14.3 $\mu \mathrm{m}$ long and 7.3-10.8 $\mu \mathrm{m}$ wide, spines excluded. Cysts are ornamented by seven longitudinal series of spines (Fig. 1G-I), whose arrangement matches that of thecal plates on the epitheca and hypotheca. No spines are present in the cingular and sulcal regions (Fig. 1G, H). Larger cells (16.9-18 $\mu \mathrm{m}$ long and $14.7-15.6 \mu \mathrm{m}$ wide), which were possibly planozygotes, were occasionally seen in the culture.

\section{Pigments}

HPLC analysis confirmed the presence of chlorophyll $c_{2}$, peridinin, cis-peridinin, dinoxanthin, $\beta, \beta$-carotene and the xanthophyll cycle pigments, diadinoxanthin and diatoxanthin (Fig. 2). The percent composition ( $\%$ of total weight) shows that peridinin is the major accessory pigment (34.7\%, Table 3), followed by chl $c_{2}(10.5 \%)$ and diadinoxanthin $(5.6 \%)$, all the other pigments account- ing for less than 2\% (Table 3). Minor amounts of chl $a$ derivatives, allomer and epimer, were present, accounting for $4 \%$ of the sum of chl $a$ and these derivatives.

Phylogenetic relationships

The SSU of rDNA of strain CCMP 2088 is 1,794 bp long; the whole sequence was included in the analysis.

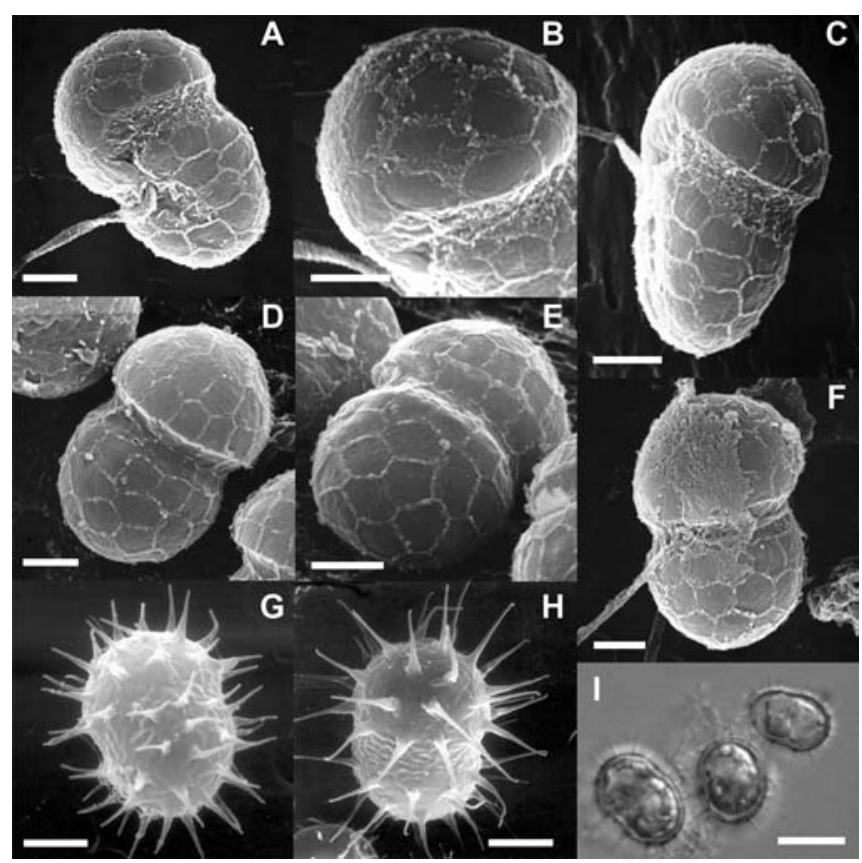

Fig. 1A-I Polarella glacialis (strain CCMP 2088), SEM (A-H) and light (I) micrographs of vegetative cells and cysts. Vegetative cell, ventral view (A); the same cell, detail of the epitheca (B); the same cell, lateral view $(\mathbf{C})$; vegetative cell, dorsal view $(\mathbf{D})$; the same cell tilted to show the antapical part of the hypotheca (E); dorsal view of a vegetative cell partially covered by the external membrane covering the thecal plates $(\mathbf{F})$; resting cyst, ventral view $(\mathbf{G})$; resting cyst, apical-ventral view (H); resting cysts, light micrograph (I). Scale bars: A-F $2 \mu \mathrm{m} ; \mathbf{G}, \mathbf{H} 5 \mu \mathrm{m} ;$ I $10 \mu \mathrm{m}$ 
Fig. 2 HPLC chromatogram showing the pigment composition of a culture sample of CCMP 2088. Peak absorbance at $450 \mathrm{~nm}$ is presented as a function of retention time on the column. Chromatographic conditions are given in the text $(C h l=$ hlorophyll $)$

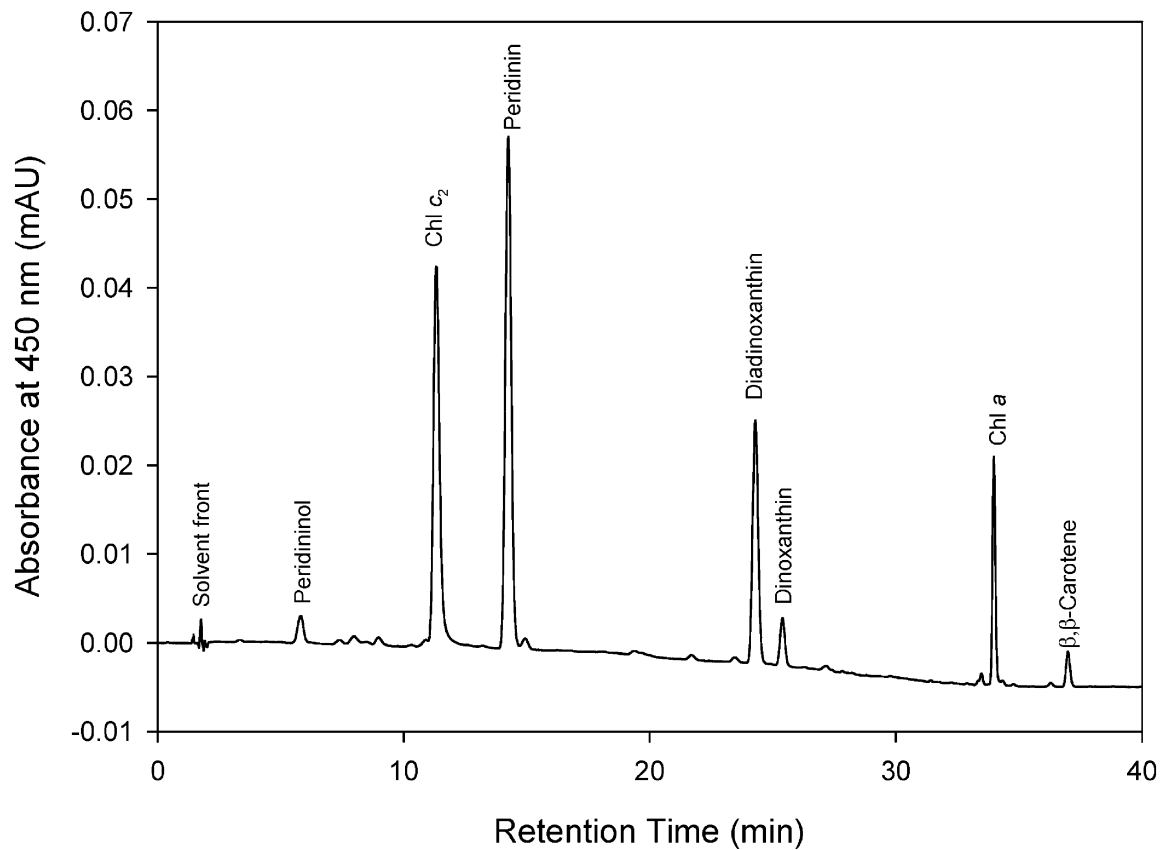

Calculation of $g_{1}$ confirms the informativeness of our data set, showing a value of -0.60 , which is significantly lower than the theoretical threshold value $(-0.09$, at $P=0.01)$ calculated for the 50 taxa we analysed and the 554 parsimony informative characters. Distance and parsimony trees showed the same topology and only the distance tree is shown here (Fig. 3). The SSU rDNA phylogenetic trees show a clear polytomy at the base. However, the clade grouping all Symbiodinium spp., Gymnodinium béii, G. simplex, Polarella glacialis and the Arctic isolate CCMP 2088 has an extremely strong bootstrap support (100\%). Within this major clade, two subclades were evident. All of the Symbiodinium species ( $100 \%$ bootstrap support) were in the first group, and Polarella glacialis from the Antarctic (CCMP 1383), the Arctic isolate CCMP 2088, along with G. béii and G. simplex ( $98 \%$ bootstrap support), were in the second group. Sequence polymorphism, calculated for Polarella glacialis (strain CCMP 1383) and strain CCMP 2088, showed a similarity value of $99.7 \%$. Six variable sites were detected between the two sequences, none of which were parsimony informative.

\section{Discussion}

Our investigation demonstrated that the gross morphology of motile cells and cysts and the plate pattern of motile cells of the Arctic dinoflagellate strain CCMP 2088 fit those described for Polarella glacialis, a species recently described from the Antarctic (Montresor et al. 1999). HPLC analysis showed a general similarity in percent composition of pigments among the Arctic strain CCMP 2088 and two Antarctic strains of Polarella glacialis (CCMP 1383 and FL1B, Thomson et al. 2003). All these isolates showed a pigment composition typical of most dinoflagellates (Jeffrey et al. 1997), dominated by the accessory carotenoid peridinin, the only difference being a slightly higher content of chl $c_{2}$ and peridinin in strain CCMP 2088.

Molecular analyses showed that the two strains group in the same strongly supported clade and their SSU rDNA sequences are characterised by high similarity values, differing only by six base pairs. The level of divergence recorded between the two strains in a relatively conserved region such as the SSU rDNA, raises questions concerning the assignment of the two strains to the same species. There are no absolute rules for determining taxonomic rank among protists (Patterson 1999), and defining species boundaries among closely related taxa is somewhat arbitrary. Although molecular data are valid for testing genetic relationships among closely related taxa, in order to assign genotypes to different

Table 3 Photosynthetic pigment content and composition ( $\%$ of total pigments) of strain CCMP 2088, compared with cultures of Antarctic Polarella glacialis (strain CCMP 1383 and Davis sea-ice strain FL1B, from Thomson et al. 2003)

\begin{tabular}{|c|c|c|c|}
\hline Pigment & CCMP 2088 & CCMP 1383 & FL1B \\
\hline Total Chl $a\left(\mu \mathrm{g} \mathrm{ml}^{-1}\right)$ & 0.5 & 0.2 & 0.3 \\
\hline Chla:Chl $c_{2}$ wt ratio & 3.9 & 8.5 & 7.7 \\
\hline Peridinin:Chl $a$ wt ratio & 0.9 & 0.5 & 0.7 \\
\hline \multicolumn{4}{|l|}{$\begin{array}{l}\text { Percent composition } \\
(\% \text { of total pigment } \mathrm{wt})\end{array}$} \\
\hline Chl $a$ (incl. allomer + epimer) & 44.3 & 51.2 & 44.3 \\
\hline $\mathrm{Chl} c_{2}$ & 10.5 & 6.1 & 5.7 \\
\hline Peridinin & 34.7 & 24.4 & 31.1 \\
\hline Cis-Peridinin & 1.7 & 1.3 & 1.1 \\
\hline Dinoxanthin & 1.8 & 2.1 & 2.4 \\
\hline Diadinoxanthin & 5.6 & 11.0 & 10.9 \\
\hline Diatoxanthin & 0.1 & 0 & 0 \\
\hline$\beta, \beta$-carotene & 1.3 & 1.3 & 1.6 \\
\hline
\end{tabular}


Fig. 3 Phylogenetic tree derived from Kimura-3-parameter distance model using Neighbour Joining reconstruction. The bootstrap support has been calculated for 1,000 replicates; only bootstrap values $>50 \%$ are shown

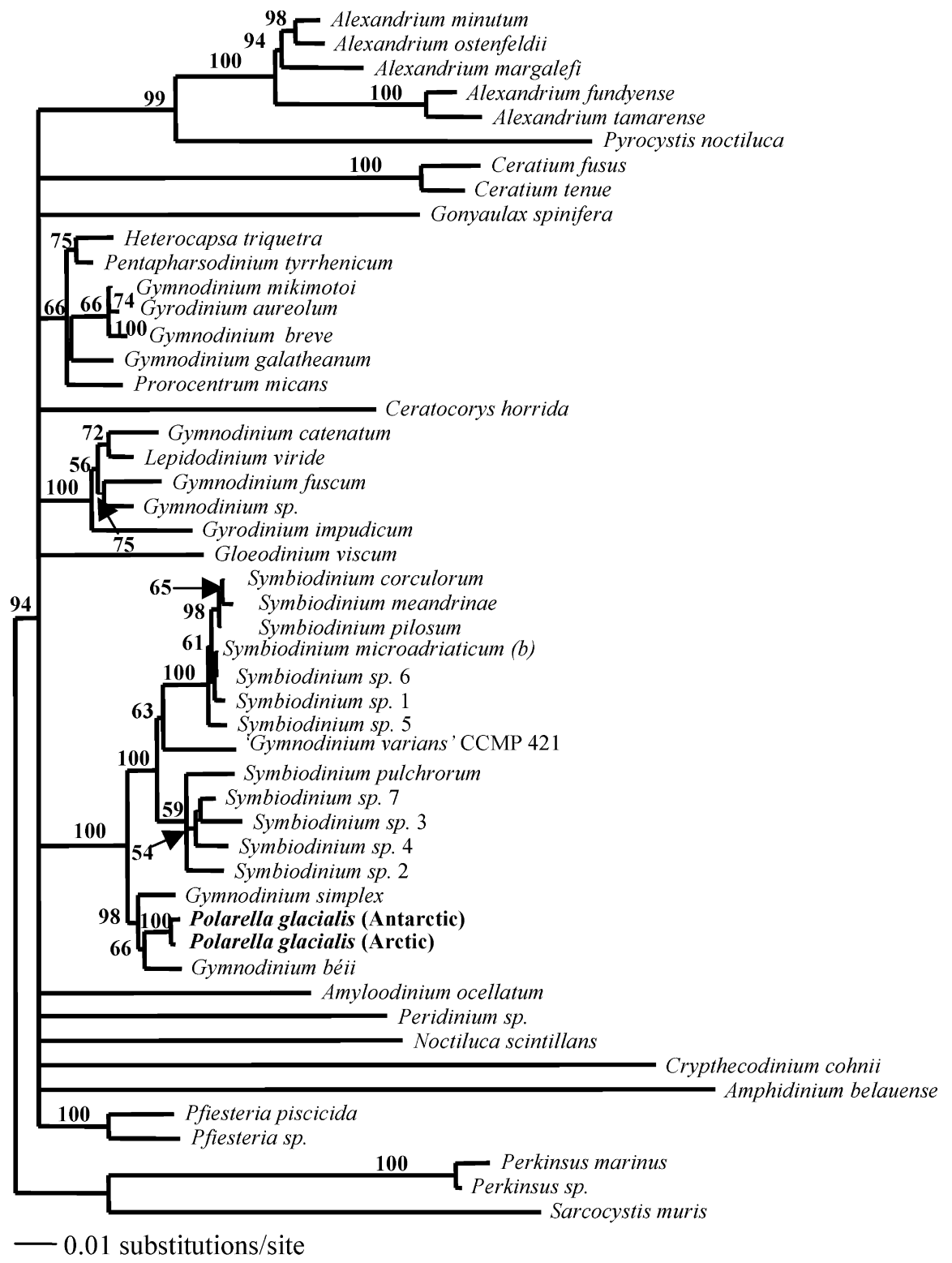

taxonomic entities, genetic information must be corroborated by information on morphological features, life-cycle or ecological traits (e.g. Medlin et al. 1991; Page and Charleston 1997; Larsen 1999; Templeton et al. 2000; Nichols 2001). The same DNA regions evolve at different rates even among similar organisms (Pawlowski et al. 1997). Moreover, cryptic species, morphologically identical but genetically distinct populations (van Oppen et al. 1996; Montresor et al. 2003), confound the interpretation of genetic versus classical morphology-based taxonomy.

Geographical separation is an important mechanism for speciation, even among planktonic groups (Palumbi 1994), but there are few studies of bipolar protist distributions using molecular techniques. Darling et al. (2000) described patterns of genetic divergence among Foraminifera species with bipolar distributions. In some recognised morphospecies, identical SSU haplotypes were present in both Arctic and Antarctic isolates while, in others, isolates from the same geographic region had up to $10 \%$ sequence variability. Among photosynthetic taxa, Phaeocystis pouchetii and Phaeocystis antarctica are abundant colony-forming haptophytes that have been described as two distinct species, although their SSU rDNA sequences differ by only six to seven nucleotides (Medlin et al. 1994), a genetic distance comparable to that recorded among the Arctic and Antarctic strains of Polarella. Phaeocystis pouchetii is common in cold temperate regions in the northern hemisphere, while Phaeocystis antarctica is restricted to the Southern Ocean. In addition to differences in the SSU rDNA sequences, the two species are morphologically distinct both in their colonial and motile stages. Moreover the northern hemisphere and Antarctic Phaeocystis have different growth-temperature ranges (Medlin et al. 1994). In this case, with discernible morphological and 
ecological differences, the two forms of Phaeocystis are considered different species.

Compared to planktonic forms, there are fewer investigations using molecular techniques aimed at testing the genetic structure of sea-ice-biota organisms with bipolar distribution (Vincent 2000). Circumpolar distributions may be a common feature for planktonic organisms, due to the mixing effect of the Antarctic Circumpolar Current which encircles the Antarctic continent every 1-2 years and the large-scale transport processes over the Arctic Basin (Aagaard and Carmack 1994). Thomson et al. (2003) indeed found that populations of Polarella glacialis from opposite sides of Antarctica (CCMP 1383 from McMurdo Sound and an East Antarctica isolate) differed little, with $0.2 \%$ sequence divergence in 1,366 base pairs in the LSU rDNA, and suggested that the species has a circumpolar distribution. Comparable data on Arctic Polarella distribution and genetic variability are required. For the time being, we have attributed the Arctic strain CCMP 2088 to the species Polarella glacialis, although further studies on the genetic variability within the two bipolar populations, and thus on the extent of genetic flow between them, on their life-cycle, ecology and physiology could confirm or reject their co-specificity.

Our information on the biogeographic range of Polarella glacialis is scanty, with reports mainly from the Antarctic region (Garrison and Buck 1989; Buck et al. 1992; Stoecker et al. 1992, 1998; McMinn and Hodgson 1993; Marino et al. 1994; McMinn 1996; Moro et al. 2000; Thomson et al. 2003) with reports of cysts from the Arctic (Meunier 1910; Ikävalko and Gradinger 1997; Okolodkov 1998). To our knowledge, this species has only been reported from polar regions, but we cannot rule out completely the possibility that it could have a wider biogeographic range. The identification of the motile stage of this unarmoured dinoflagellate in phytoplankton samples is difficult due to the poor preservability of their shape after the routine fixation procedures. Moreover, the extremely thin thecal plates can be visualised only after SEM preparation, which further limits identification at the species level. The very distinctive spiny cyst of Polarella glacialis represents the most reliable morphological character for the detection of this species. These cysts are, however, destroyed by harsh acid treatments often used for the preparation of sediment samples and even by milder acetolysis (McMinn 1995; Montresor et al. 1999). Polarella glacialis cysts have been found in the upper centimetres of core samples collected in Antarctic waters but they were never present at greater burial depths (McMinn 1995). This confirms the reduced preservability of these cysts and hampers the possibility of reconstructing the distribution of this species even over relatively limited time scales.

The finding of Polarella glacialis both in Antarctic and Arctic sites raises interesting questions concerning the evolutionary history of this species and/or its dispersal routes. Bipolar distribution patterns have been reported for several marine plants and animals, including planktonic taxa, and several hypotheses have been put forward to explain this peculiar biogeographical pattern (e.g. Fryxell et al. 1981; Crame 1993; Pierce and Turner 1993; van Oppen et al. 1993, 1994; Darling et al. 2000). Unfortunately, there are no data allowing the calibration of a "molecular clock" for dinoflagellates and we cannot infer the time of separation of the two Polarella glacialis populations based on their genetic divergence. The two latitudinally disjunct populations could represent examples of a paleoclimatic vicariant event that could have occurred either during the Miocene (27-7 mya ago) or during the Pleistocene glacial maximum $(18,000$ years $\mathrm{BP})$. In these periods, ice margins of the two hemispheres were much closer than at the present time, and this could have allowed one population to colonise the opposite hemisphere. The tropical seawater belt constitutes a strong barrier for the survival of cold-water phytoplanktonic organisms, which rely on photosynthesis and live in surface waters. Gene flow between Arctic and Antarctic populations of planktonic foraminifers has been reported (Darling et al. 2000) and Polarella glacialis has a potential advantage over planktonic Foraminifera, since it produces resting cysts, which could provide resistance to adverse temperature and environmental conditions. It is thus possible that encysted stages of Polarella glacialis could have been transported across the tropical waters in recent times through long-range transport, either via ocean currents, atmospheric circulation, ballast waters or biological vectors, e.g. trans-polar bird migration. An alternative and highly debated hypothesis is that marine microorganisms have a cosmopolitan distribution pattern (Finlay 2002) and only in specific and favourable conditions can reach higher biomass. However, more information on the genetic structure and relatedness of marine protists are needed in order to support or reject this hypothesis.

Phylogenetic analyses place the two strains of Polarella glacialis within the major clade that groups species of the genus Symbiodinium. Physiological and molecular data provide evidence that Symbiodinium is most probably a highly diversified genus, including several cryptic species (e.g. Rowan and Powers 1992; Carlos et al. 1999) that form symbiotic associations with a wide range of marine invertebrates. Most Symbiodinium species lack readily discernible morphological features (LaJeunesse 2001), and for only a few of them has the motile, freeliving stage been described (e.g. Loeblich III and Sherley 1979; Trench and Blank 1987). The arrangement of thecal plates represents one of the most important features on which the taxonomic framework of extant and fossil dinoflagellates is based (Fensome et al. 1993). The order Suessiales was established within the subclass Gymnodiniphycidae for grouping taxa whose amphiesmal vesicles (thecal plates) are not randomly distributed around the cell, but arranged into seven to ten latitudinal series (Fensome et al. 1993). Molecular phylogenetic studies based on the sequences of the SSU nuclear 
rDNA support the monophyletic origin of the order Suessiales (Saunders et al. 1997; Montresor et al. 1999; Saldarriaga et al. 2001) and our analyses, carried out using a larger set of sequences of Symbiodinium species, further confirm this conclusion. The close phylogenetic relationship among Polarella glacialis and symbiotic dinoflagellates raises puzzling questions concerning their evolutionary history. The free-living G. simplex and the two Polarella glacialis strains have a basal position in the Suessiales clade, as compared to Symbiodinium spp. This could suggest an older lineage of free-living dinoflagellates from which endosymbiotic species could have subsequently evolved. A thin link to this hypothesis is represented by the morphological resemblance of Polarella glacialis cysts with very old fossil dinoflagellate cysts, dating back to the Triassic and Jurassic (Bucefalo Palliani and Riding 1997).

The two strains of Polarella glacialis group into a subclade of the order Suessiales, together with G. béii Spero and G. simplex (Lohmann) Kofoid and Swezy. The large genus Gymnodinium includes unarmoured species, which share the character of having epicone and hypocone of similar size. Recent ultrastructural and molecular studies provided evidence that this genus represents, in fact, an artificial lumping and that it includes markedly diversified organisms that should better be split into different genera (e.g. Daugbjerg et al. 2000). This is evident also from the results of our phylogenetic analysis, where several "Gymnodinium" species are scattered among distant clades. G. béii was described as a symbiont of the planktonic foraminifer Orbulina universa (Spero 1987). This species has a small, free-living motile stage, whose general shape is reminiscent of $\mathrm{Po}$ larella glacialis, in having a slightly conical hypotheca bearing a distinct flange projecting over the sulcus from its left side. G. béii motile cells have thin thecal plates, which are visible in TEM thin sections. However, the thecal plate pattern was not described. G. simplex is a small-sized, featureless gymnodinioid species. The presence of thin thecal plates has been illustrated (Dodge 1974) but the plate pattern is also unknown for this species. The emended diagnosis for the genus Gymnodinium states for unarmoured dinoflagellates, with a cingulum displacement of one or more cingulum width and a horseshoe-shaped apical groove running in an anticlockwise direction. Ultrastructural features include a nuclear envelope with vesicular chambers and the presence of a nuclear or dorsal fibrous connective (Daugbjerg et al. 2000). All these ultrastructural details are lacking both for $G$. béii and G. simplex. Further studies are thus necessary to achieve a correct phylogenetic assignment for these two species and to trace phylogenetic relationships among them and Polarella glacialis.

When Meunier (1910) described the genus Echinus, he was not able to place it within any known planktonic phylum. However, it is interesting to mention that he speculated about a possible rough resemblance between the spiny cells and dinoflagellates, although he pointed out the absence of cingulum and thecal plates. He also put forward the hypothesis that they could have been spores of some species living in the snow and, indeed, $E$. majus and E. minus turned out to be the cysts of Polarella glacialis. Meunier (1910) also hypothesised that these tiny cells could be symbionts of unknown organisms. We now know that Polarella glacialis has a freeliving habitus. Perhaps the confined physical space within brine channels promotes specific microbial consortia and Polarella glacialis, as part of this community, is the photosynthetic symbiont, with the sea ice providing structure! Speculations aside, the phylogenetic relationship of Polarella glacialis with endosymbiotic dinoflagellates and the basal position in the phylogenetic clade of the order Suessiales provide a stimulating perspective on the evolutionary history of this important and intriguing group of species.

Acknowledgements We would like to thank E. Biffali and the Molecular Biology Service of the Stazione Zoologica "A. Dohrn" for technical support during sequencing. Sampling was in conjunction with the International North Water Polynya project financed by the Natural Sciences and Engineering Research Council of Canada (NSERC) funds FCAR (Québec) and Fisheries and Oceans, Canada. C.L. was supported by NSERC post-graduate fellowships (PGA and PGB) throughout the study.

\section{References}

Aagaard K, Carmack EC (1994) The Arctic Ocean and climate: a perspective. In: Johannnessen OM, Muench RD, Overland JE (eds) The Polar Oceans and their role in shaping the Global environment. The Nansen Centenial Volume, Geophysical Monograph Series 85 AGU, Washington, DC, pp 5-20

Bucefalo Palliani R, Riding JB (1997) Umbriadinium mediterraneense gen. et sp. nov. and Valvaeodinium hirsutum sp. nov.: two dinoflagellate cysts from the Lower Jurassic of the Tethyan Realm. Palynology 21:197-206

Buck KR, Bolt PA, Bentham WN, Garrison DL (1992) A dinoflagellate cyst from Antarctic sea ice. J Phycol 28:15-18

Carlos AA, Baillie BK, Kawachi M, Maruyama T (1999) Phylogenetic position of Symbiodinium (Dinophyceae) isolates from tridacnids (Bivalvia), cariids (Bivalvia), a sponge (Porifera), a soft coral (Anthozoa), and a free-living strain. J Phycol 35:1054-1062

Crame J (1993) Bipolar mollusks and their evolutionary implications. J Biogeogr 20:145-161

Darius H, Martin P, Grimont P, Dauga C (2000) Small subunit rDNA sequence analysis of symbiotic dinoflagellates from seven scleractinian corals in a Tahitian lagoon. J Phycol 36:951-959

Darling KF, Wade CM, Stewart IA, Kroon D, Dingle R, Brown AJL (2000) Molecular evidence for genetic mixing of Arctic and Antarctic subpolar populations of planktonic foraminifers. Nature 405:43-47

Daugbjerg N, Hansen G, Larsen J, Moestrup Ø (2000) Phylogeny of some of the major genera of dinoflagellates based on ultrastructure and partial LSU rDNA sequence data, including the erection of three new genera of unarmoured dinoflagellates. Phycologia 39:302-317

Dodge JD (1974) A redescription of the dinoflagellate Gymnodinium simplex with the aid of electron microscopy. J Mar Biol Assoc UK 54:171-177

Fensome RA, Taylor FJR, Norris G, Sarjeant WAS, Wharton DJ, Williams GL (1993) A classification of living and fossil dinoflagellates. Micropaleontology Special Publication no 7. Sheridan, Hanover, $\mathrm{Pa}$ 
Finlay BJ (2002) Global dispersal of free-living microbial eukaryote species. Science 296:1061-1063

Fryxell GA, Doucette GJ, Hubbard GF (1981) The genus Thalassiosira: the bipolar diatom T. antarctica Comber. Bot Mar 24:321-335

Garrison DL, Buck KR (1989) The biota of Antarctic pack ice in the Weddell Sea and Antarctic peninsula region. Polar Biol 10:211-219

Gast RJ, Caron DA (1996) Molecular phylogeny of symbiotic dinoflagellates from planktonic foraminifera and radiolaria. Mol Biol Evol 13:1192-1197

Hall TA (1999) BioEdit: a user-friendly biological sequence alignment editor and analysis program for Windows 95/98/NT. Nucleic Acids Symp Ser 41:95-98

Hillis DM, Huelsenbeck JP (1992) Signal, noise, and reliability in molecular phylogenetic analyses. J Hered 83:189-195

Ikävalko J, Gradinger R (1997) Flagellates and heliozoans in the Greenland Sea ice studied alive using light microscopy. Polar Biol 17:473-481

Jeffrey SW, Mantoura RFC, Wright SW (1997) Phytoplankton pigments in oceanography. UNESCO, Paris

Keller MD, Selvin RC, Claus W, Guillard RRL (1987) Media for the culture of oceanic ultraphytoplankton. J Phycol 23:633-638

Klimyuk VI, Carrol BJ, Thomas CM, Jones JDG (1993) Alkali treatment for rapid preparation of plant material for reliable PCR analysis. Plant J 3:493-494

LaJeunesse TC (2001) Investigating the biodiversity, ecology, and phylogeny of endosymbiontic dinoflagellates in the genus Symbiodinium using the ITS region: in search of a "species" level marker. J Phycol 37:866-880

Langer MR, Lipps JH (1995) Phylogenetic incongruence between dinoflagellate endosymbionts (Symbiodinium) and their host foraminifera ( Sorites): small-subunit ribosomal RNA gene sequences evidence. Mar Micropaleontol 26:179-186

Larsen A (1999) Prymnesium parvum and P. patelliferum (Haptophyta) - one species. Phycologia 38:541-543

Litaker RW, Tester PA, Colorni A, Levy MG, Noga EJ (1999) The phylogenetic relationship of Pfiesteria piscicida, cryptoperidiniopsoid sp. Amyloodinium ocellatum and a Pfiesteria-like dinoflagellate to other dinoflagellates and apicomplexans. J Phycol 35:1379-1389

Loeblich III AR, Sherley JL (1979) Observations on the theca of the motile phase of free-living and symbiotic isolates of Zooxanthella microadriatica (Freudenthal) comb. nov. J Mar Biol Assoc UK 59:195-205

Marino D, Montresor M, Mazzella L, Saggiomo V (1994) Diatom flora in oval faecal pellets from Terra Nova Bay (Antarctica). In: Marino D, Montresor M (eds) Proceedings of the 13th International Diatom Symposium. Biopress, Bristol, pp 229-240

McMinn A (1995) Why are there no post-Palaeogene dinoflagellate cysts in the Southern Ocean? Micropaleontology 41:383-386

McMinn A (1996) Preliminary investigation of the contribution of fast-ice algae to the spring phytoplankton bloom in Ellis Fjord, eastern Antarctica. Polar Biol 16:301-307

McMinn A, Hodgson D (1993) Summer phytoplankton succession in Ellis Fjord, eastern Antarctica. J Plankton Res 15:925-938

Medlin LK, Elwood HJ, Stickel S, Sogin ML (1991) Morphological and genetic variation within the diatom Skeletonema costatum (Bacillariophyta): evidence for a new species, Skeletonema pseudocostatum. J Phycol 27:514-524

Medlin LK, Lange M, Baumann MEM (1994) Genetic differentiation among three colony-forming species of Phaeocystis: further evidence for the phylogeny of the Prymnesiophyta. Phycologia 33:199-212

Meunier A (1910) Microplancton des Mers de Barents et de Kara. Duc d'Orléans, Campagne Arctique de 1907. Bulens, Brussels

Montresor M, Procaccini G, Stoecker DK (1999) Polarella glacialis gen. nov., sp. nov. (Dinophyceae): Suessiaceae are still alive! J Phycol 35:186-197

Montresor M, Sgrosso S, Procaccini G, Kooistra WHCF (2003) Intraspecific diversity in Scrippsiella trochoidea (Dinophyceae): evidence for cryptic species. Phycologia (in press)
Moro I, Paccagnella R, Barbante C, Andreoli C (2000) Microalgal communities of the sea ice, ice-covered and ice-free waters of Wood Bay (Ross sea, Antarctica) during the austral summer 1993-94. PSZNI Mar Ecol 21:233-245

Nichols R (2001) Genes trees and species trees are not the same. Trends Ecol Evol 16:358-364

Okolodkov JB (1998) A checklist of dinoflagellates recorded from the Russian Arctic seas. Sarsia 83:267-292

Oldach DW, Delwiche CF, Jacobsen KS, Tengs T, Brown EG, Kempton JW, Schaefer EF, Bowers HA, Glasgow HB, Burkholder J-AM, Steidinger KA, Rublee PA (2000) Heteroduplex mobility assay-guided sequence discovery: elucidation of the small subunit (18S) rDNA sequences of Pfiesteria piscicida and related dinoflagellates from complex algal culture and environmental sample DNA pools. Proc Natl Acad Sci USA 97:4303-4308

Oppen MJH van, Olsen JL, Stam WT, van den Hoek C, Wiencke C (1993) Arctic-Antarctic disjunctions in the benthic seaweeds Acrosiphonia arcta (Chlorophyta) and Desmarestia viridis/willii (Phaeophyta) are of recent origin. Mar Biol 115:381-386

Oppen MJH van, Dieckmann OE, Wienke C, Stam WT, Olsen JL (1994) Tracking dispersal routes: phylogeography of the ArcticAntarctic disjunct seaweed Acrosyphonia arcta (Chlorophyta). J Phycol 30:67-80

Oppen MJH van, Klerk H, Olsen JL, Stam WT (1996) Hidden diversity in marine algae: some examples of genetic variation below the species level. J Mar Biol Assoc UK 76:239-242

Page RDM, Charleston MA (1997) From gene to organismal phylogeny: reconciled trees and the gene tree/species tree problem. Mol Phylogenet Evol 7:231-240

Palumbi SR (1994) Genetic divergence, reproductive isolation and marine speciation. Annu Rev Ecol Syst 25:547-572

Patterson DJ (1999) The diversity of Eukaryotes. Am Nat 65S:96124

Pawlowski J, Bolivar I, Fahrni JF, De Vargas C, Gouy M, Zaninetti L (1997) Extreme differences in rates of molecular evolution of Foraminifera revealed by comparison of ribosomal DNA sequences and the fossil record. Mol Biol Evol 14:498505

Pierce RW, Turner JT (1993) Global biogeography of marine tintinnids. Mar Ecol Prog Ser 94:11-26

Rowan R, Powers DA (1992) Ribosomal RNA sequences and the diversity of symbiotic dinoflagellates (zooxanthellae). Proc Natl Acad Sci USA 89:3639-3643

Rozas J, Rozas R (1999) DnaSP version 3: an integrated program for molecular population genetics and molecular evolution analysis. Bioinformatics 15:174-175

Saldarriaga JF, Taylor FJR, Keeling PJ, Cavalier-Smith T (2001) Dinoflagellate nuclear SSU rRNA phylogeny suggests multiple plastid losses and replacement. J Mol Evol 53:204-213

Saunders GW, Hill DRA, Sexton JP, Andersen RA (1997) Smallsubunit ribosomal RNA sequences from selected dinoflagellates: testing classical evolutionary hypotheses with molecular systematic methods. In: Bhattacharya D (ed) Origins of algae and their plastids. Springer, Berlin Heidelberg New York, pp 237-259

Sokal RR, Rohlf FJ (1981) Biometry. Freeman, San Francisco

Spero HJ (1987) Symbiosis in the planktonic foraminifer, Orbulina universa, and the isolation of its symbiotic dinoflagellate Gymnodinium béii sp. nov. J Phycol 23:307-317

Stoecker DK, Buck KR, Putt M (1992) Changes in the sea-ice brine community during the spring-summer transition, McMurdo Sound, Antarctica. I. Photosynthetic protists. Mar Ecol Prog Ser 84:265-278

Stoecker DK, Gustafson DE, Merrell JR, Black MMD, Baier CT (1997) Excystment and growth of chrysophytes and dinoflagellates at low temperatures and high salinities in Antarctic seaice. J Phycol 33:585-595

Stoecker DK, Gustafson DE, Black MMD, Baier CT (1998) Population dynamics of microalgae in the upper land-fast sea ice at a snow-free location. J Phycol 34:60-69 
Stoecker DK, Gustafson DE, Baier CT, Black MMD (2000) Primary production in the upper sea ice. Aquat Microb Ecol 21:275-287

Swofford DL (2002) PAUP*_Phylogenetic Analysis Using Parsimony (* and other methods) Version 4.0b10. Sinauer, Sunderland, Mass

Templeton AR, Maskas SD, Cruzan MB (2000) Gene trees: a powerful tool for exploring the evolutionary biology of species and speciation. Plant Species Biol 15:211-222

Tengs T, Dahlberg OJ, Shalchian-Tabrizi K, Klaveness D, Rudi K, Delwiche CF, Jakobsen KS (2000) Phylogenetic analyses indicate that the 19'hexanoyloxy-fucoxanthin-containing dinoflagellates have tertiary plastids of haptophyte origin. Mol Biol Evol 17:718-729

Thompson JD, Higgins DG, Gibbson TJ (1994) Clustal W: improving the sensitivity of progressive multiple sequence alignment through sequence weighting, position-specific gap penalties and weight matrix choice. Nucleic Acids Res 22:46734680

Thomson PG, Nichols P, Bolch C, Skerratt J, Wright S, McMinn A (2003) Antarctic distribution, pigment and lipid composition and molecular identification of the brine dinoflagellate Polarella glacialis (Dinophyceae). J. Phycol (in press)
Throndsen J (1995) Estimating cell numbers. In: Hallegraeff GM, Anderson DM, Cembella AD (eds) Manual on harmful marine microalgae. UNESCO, Paris, pp 63-80

Toller WW, Rowan R, Knowlton N (2001) Zooxanthellae of the Montastraea annularis species complex: patterns of distribution of four taxa of Symbiodinium on different reefs and across depths. Biol Bull Woods Hole 201:348-359

Trench RK, Blank RJ (1987) Symbiodinium microadriaticum Freudenthal; S. goreauii sp. nov; S. kawagutii sp. nov. and S. pilosum sp. nov. : gymnodinioid dinoflagellate symbionts of marine invertebrates. J Phycol 23:469-481

Vincent WF (2000) Evolutionary origins of Antarctic microbiota: invasion, selection and endemism. Antarct Sci 12:374-385

Zapata M, Rodriguez F, Garrido JL (2000) Separation of chlorophylls and carotenoids from marine phytoplankton: a new method using reversed-phase C8 column and pyridine-containing mobile phases. Mar Ecol Prog Ser 195:29-45 